Ortwin de Graef (K.U.Leuven)

\title{
Epistle to the Europeans (On Not Reading Kipling)*
}

There are nine and sixty ways of constructing tribal lays, / And-every-single-one-ofthem-is-right! (Rudyard Kipling, "In the Neolithic Age")1

But what is the peculiarity of a good bad poem? A good bad poem is a graceful monument to the obvious. (George Orwell, "Rudyard Kipling”)

The thesis I want to advance in this essay is pretty trivial: the success of a literary artefact's contribution to the formation of (collective) identities depends on the extent to which it manages to elude reading by commanding thoughtless assent. If it weren't so trivial, we might call it the propaganda paradox; as it is, we should perhaps just call it the propaganda principle. The reason why I nonetheless propose to advance this principle yet again is that it is so often and so stubbornly denied - most significantly so by way of deferential expressions of admiration for the putative performative power of literature as a discourse that is properly untouched by the propaganda principle and whose effectiveness depends on the accuracy of its articulation of the constitutive elements of identity formation.

The case I want to consider is a core classic of the British Imperial canon. If that seems unlikely to further advance the cause of European integration, that is probably a good thing. Indeed, one of the admittedly uncontroversial points I would like to draw from this case is that the notion of integration is fatally flawed by its family resemblance to the retrograde notion of the nation. Conversely, and slightly less trivially, I would like to suggest that Europe - the very idea - has a historical chance to haunt both nation and integration into the non-state of nature where they belong - a chance, to be sure, which continues to be lost, and will remain so as long as we (who, we?) persist in refusing to read.

This paper has benefited greatly from discussions with Benjamin Biebuyck, Gert Buelens, and Sigi Jöttkandt, my colleagues on the Fund for Scientific Research - Flanders (Belgium) research project "A Critique of Literary Ethics: Metaphor, Metonymy, and Synecdoche in Anglo-American Poetry and Prose of the Nineteenth Century."

$1 \quad$ See Orwell 193 n.1. 
Who, we? Let us say, provisionally, We Europeans, alluding to the title of a 1935 book by Julian Huxley, A.C. Haddon, and A.M. Carr-Saunders, subtitled A Survey of "Racial" Problems, which sets out to present the then available "scientific facts [...] on the subject of 'race' in man [...] in the light of established scientific principles" (7). A vintage piece of committed popular science writing, the book distinguishes what the authors refer to "by the noncommittal phrase 'group sentiment" " "the sentiment which animates tribal and national units alike") from notions of "race," authoritatively rubbishing the sinister "claims to 'racial unity' [...] in recent nationalist controversy," and singling out for cool ridicule the notion of the "chosen people" typically informing such discourse $(15,19)$. By way of illustration, the authors note that "some of the noblest claims made for the British, by Mr. Kipling for instance, are closely similar to the claims made for the tribes of Israel by the authors of certain Biblical books," and suggest as evidence a comparison between "The White Man's Burden" and a passage from Isaiah in which the Lord proposes to give Israel "for a light to the Gentiles" (20). Passing over the complication that Kipling's "White Man" is not particularly British, while those he sets out to release from the "bondage" of their "loved Egyptian night" are typologically cast as anything other than Gentiles, ${ }^{2}$ I want to turn to another poem Kipling wrote at about the same time which explicitly mentions the Gentiles in such a way that the close similarity suggested in Huxley's comparison collapses into identity - assuming we know what that means - and the chosen people are troped beyond recognition.

But before turning to this alternative text, I want to dwell for a moment on the significance of Kipling's quotability in Huxley's text. His “noblest claims for the British" are indeed just quoted, juxtaposed to a quotation from the Bible without further comment other than that allowance should be made "for differences of atmosphere and language" (19). What is important here is that any potential irony we might imagine in this juxtaposition of the Bible and Kipling is indeed left to our imagination - and any such imagination should be checked by an appreciation of Kipling's status at the time We Europeans was published, one year before his death. His greatest triumphs as one of the most popular poets in world history (recorded also by his being awarded the Nobel Prize in Literature in 1907) lay some decades behind him 
then, but placing his writing alongside Scripture was not as absurd then as it may seem to us now. Who, we? Perhaps it still should not be more absurd to quote Kipling than it is to quote Scripture. Huxley and his fellow authors, at any rate, leave any potential venom in the comparison unvoiced. Their express ridicule is reserved particularly for Madison Grant, whose 1916 The Passing of the Great Race: The Racial Basis of European History launched the so-called "Nordic theory" which would prove to be so germane to the Nazi imagination. Implicitly, this ridicule must also affect both Kipling and the Bible, but that implication is not spelled out. This would appear to allow for a difference more substantial than that of "atmosphere and language" obtaining between Kipling and the Prophets - a difference between, on the one hand, the poet-prophets or prophet-poets and, on the other, the unsound scientists, whose work Huxley likens to false Scripture: "We all know that the Devil can quote Scripture for his own purpose: today we are finding that he can even invent a false Scripture from which to quote" (7). False Scripture, it would seem, must be read; Scripture, including Kipling, is only quoted. "Lest we forget!" He always does have the best tunes.

The Diamond Jubilee celebrations of 1897 offered Britain ample opportunity to congratulate itself on the state of its Empire. Occasions such as this are always likely to bring out the worst in any Poet Laureate, as invariably they did in Alfred Austin, who had been appointed to the position, vacant for four years since Tennyson's death, in 1896. Kipling had been either denied the post or had refused it, and resented command performances anyway, but after some prompting he nonetheless reluctantly produced his "sentiments on things" a couple of weeks after the celebrations, in a poem published in The Times on the same page as a message from the Queen thanking the people for their jubilations. "Recessional" was a runaway success and became "the most popular poem in the English language over the first half of the twentieth century" (Kucich 60; also Parry 79); according to Kipling's recent biographer David Gilmour, the poem effectively won its author recognition as unofficial Imperial Laureate, "a national symbol, a one-man embodiment of the Empire with a talent for anticipating a public sentiment (as well as encouraging and

3 For information on Kipling's Diamond Jubilee writing, see Newsom, Judd, Keating 114-17 and Gilmour 119-25. The phrase "my sentiments on things" occurs in the letter to The Times accompanying the manuscript of the poem and is quoted in Birkenhead 185-86. 
perhaps moulding it) just before it became apparent" (124). Still according to Gilmour, "Recessional" (alongside the other anthems Kipling composed around this time) "demonstrates Kipling's extraordinary gift for persuading people that what they were reading was how they felt" (119). This assumes, of course, that people were indeed reading when they read what they felt - that the people was reading when it felt what it read. A closer look at the text and its reception suggests that this assumption is highly debatable, that feeling the feeling precisely requires the suspension of reading.

But, what, first, is the feeling, what are the "sentiments on things," the "idea" which, as Kipling himself remarked, "must have been in the air or men would not have taken to the rhymed expression of it so kindly" (quoted in Gilmour 123). Unsurprisingly, it is a pretty simple idea, neatly caught in Kipling's own summary statement in the letter accompanying the manuscript: "We've been blowing up the Trumpets of the New Moon a little too much for White Men, and it's about time we sobered down" (quoted in Birkenhead 186). Not a very hard idea to have - pride before a fall, beware of hubris, how the mighty are fallen, look on my works, ye mighty, and despair, whatever. Yet that is not how it reads in "Recessional." The poem comes in five six-line stanzas, the first four stanzas each ending (with one minor variation) on the imploring couplet "Lord God of Hosts, be with us yet, / Lest we forget - lest we forget!" The four lines preceding the rhyming couplets address God "beneath whose awful Hand we hold / Dominion" and envisage the future dissolution of Empire alongside the misconduct of its subjects, while the final stanza asks for "Thy Mercy on Thy People, Lord!" None of this seems especially arresting or challenging - easy to feel, until we begin to read.

The phrase Kipling, by his own account, "wrote the poem around" (Judd 38 ) is the mantra "Lest we forget," which is repeated eight times, and which prompts yet again our idiot question: who, we, exactly? Stanza 4 comes closest to articulating an answer by taking recourse to the us-them-scheme that invariably accompanies collective identity-constructions. But that is not to suggest this expression of "group sentiment" also makes sense.

If, drunk with sight of power, we loose

Wild tongues that have not Thee in awe,

Such boastings as the Gentiles use, 
Or lesser breeds without the Law -

Lord God of Hosts, be with us yet,

Lest we forget - lest we forget!

The sentiment is clear enough: if we get carried away, Lord, and start to speak like they do, please have mercy. But who they? The "Gentiles." And, or or, "lesser breeds without the law."

The latter phrase has always been a bit of an albatross for Kipling commentators, and not just for his admirers among them. George Orwell, for instance, whose candid characterization of Kipling as a "morally insensitive" and "aesthetically disgusting" "jingo imperialist" with "a definite strain of sadism in him" (184) leaves little to be desired, nonetheless goes out of his way to set the record straight on what he describes as this "interesting instance of the way in which quotations are parroted to and fro without any attempt to look up their context or discover their meaning":

This line is always good for a snigger in pansy-left circles. It is assumed as a matter of course that the "lesser breeds" are "natives," and a mental picture is called up of some pukka sahib in a pith helmet kicking a coolie. In its context the sense of the line is almost the exact opposite of this. The phrase "lesser breeds" refers almost certainly to the Germans, and especially the pan-German writers, who are "without the Law" in the sense of being lawless, not in the sense of being powerless. (184-85)

Orwell does not explain how exactly he has arrived at this almost certainly almost exactly opposite alternative reading, but then Orwell is not a literary historian, let alone a Kipling scholar, and can afford to move on to higher perceptions. Yet professional historians and Kipling scholars so far have not convincingly succeeded in moving beyond Orwell's homely hermeneutical appeal to context. C.A. Bodelsen, for instance, blithely dismisses the 'pansyleft' interpretation as "a curious example of the tenacity of obviously mistaken readings, for the context makes it quite clear that it is aimed at power-drunk militaristic Great Powers" (335), while the historian Denis Judd merely remixes Orwell's "almost certainly" into a "not necessarily"-"surely"-riff:

The "lesser breeds without the law" were not necessarily, as was so quickly assumed by critics of the poem, the black or brown citizens of Britain's empire. The poet is surely here referring both to foreigners and to those British citizens and subjects, no matter what their origin or ethnicity, who were unable or 
unwilling to see what needed to be done in the national interest and what perils and spectres lurked in the shadows. (41)

Judd interestingly spells out the indifference to the trope of ethnicity which also informs Orwell's interpretation, stating in so many words that lesser breeds can be British too. Another historian, Robert Tombs, follows suit (admittedly in passing and in a different context), asserting, again without argument other than context quotation, that the meaning of the phrase is "not inferior races, but nations (not excluding [Kipling's] own) that indulged in demagogic extremism and relied on force uncontrolled by moral values" (503-04).

The consensus among commentators appears to be, then, that it is somehow obvious that "lesser breeds" cannot possibly mean inferior "natives" or "races," principally because of the context, stupid. Kipling's appeal to group sentiment here would therefore seem to by-pass the racial fallacy of the chosen people, suggesting that belonging to the chosen people is a matter of choice rather than being chosen. Ethnicity does not enter into it. Except, that is, in the term "Gentiles," which is the Vulgate translation, carried over into the Authorized Version, of the Greek "ta ethne," which itself translates the Hebrew "ha goyim.." That, too, is part of the context, and despite the Biblethumping of his hermeneutico-historical apologists, it really does not help to make Kipling's meaning more manageable. And lest I be misunderstood, let me just insist that Kipling-bashing is a game I take no interest in - I am only trying to read what he wrote, which, for what it is worth, is more than can be said of most readers of "Recessional."

Consider David Gilmour's attempt to settle the matter. He recognizes that "lesser breeds without the law" "was an unfortunate and perhaps tasteless choice of phrase," but insists that it should not be interpreted as a "racial slur" (122). But what then does it mean, if anything? Gilmour turns to Scripture for enlightenment and singles out Paul's Epistle to the Romans as " $[\mathrm{t}] \mathrm{he}$ relevant biblical text": "For as many have sinned without law shall also perish without law: and as many have sinned in the law shall be judged by the law [...] For when the Gentiles, which have not the law, do by nature the things contained in the law, these, having not the law, are a law unto themselves"

$4 \quad$ For an interesting reflection on the term "ethnic" which reminds us that the $O E D$ traces its current usage to Huxley's We Europeans, see Arac 265-66. 
$(2: 12,14)$. And lest we have forgotten what this means, Gilmour spells out the relevance:

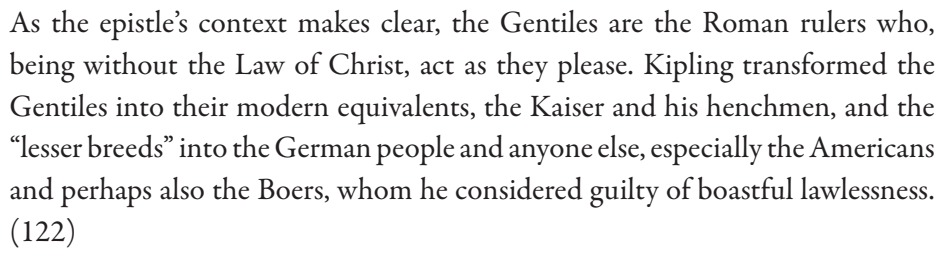

What wonderful powers of transformation are here. Orwell would have had a field day on "the Kaiser and his henchmen" as an exhibit for "Politics and the English Language," and it might have given him some welcome pause for thought about his own insouciant translation of the "lesser breeds" as "the Germans." It would certainly have further fuelled his doubts "whether the blimps have ever read [Kipling] with attention, any more than they have read the Bible" (Orwell 188).

Gilmour, blimp or not, clearly hasn't bothered. The only reference he submits for his understanding of the Epistle to the Romans is a letter to the editor published in a 1967 issue of the Kipling Journal by one of his predecessor-biographers, the long-serving and, by his own admission, long-suffering Kipling scholar C.E. Carrington. ${ }^{5}$ Carrington's letter makes interesting reading, beginning as it does by establishing a distinction between those who do and those who do not read: "Those of us who read the works of Kipling are perpetually tormented by the eminent literary critics who pontificate about him without having read them." The "lesser breeds without the law"-phrase is a case in point: "Your readers will not need to be told, as leader-writers for The Times must still be told, that Kipling could not possibly have meant to allude to the colonial peoples - whatever he did mean - by these famous words." Readers who read know what the phrase does not mean. But, once more, wearily, what then does it mean? Carrington, preaching to the converted, can afford to move into confessional mode: "I have been correcting the error in essays, and on platforms, without visible effect, for many years; and I am ashamed to confess that I have missed the clue." This clue, he goes on, was already revealed

5 I owe a debt of gratitude to David Page, the Kipling Journals current editor, who has kindly supplied me with this Carrington piece and other relevant materials from the journal, including interesting commemorative pieces on the occasion of Carrington's death in 1990. 
in a 1930 book by R. Thurston Hopkins, who pointed out that the phrase was "directly lifted" from Paul's Epistle to the Romans, as Carrington then demonstrates by quoting verses 12 and 14 from the second chapter of the Epistle, copied later by Gilmour, ${ }^{6}$ and by adding his final gloss:

Throughout this epistle, so relevant to the problems of our own age, St. Paul refers to the Roman ruling class as "the Gentiles," to whom the "oracles of God" have not been committed. The pagan Romans in their arrogant boastings, are the "lesser breeds," and, of course, so are their modern counterparts.

Of course. Paul's Epistle sets up the familiar us-them-scheme conducive to group sentiment, and Kipling just copies the set-up, translating the boasting Gentiles into a generic modern lawless "them" and claiming the "us"-slot for the law-abiding true Brits. Just so. And this, according to Gilmour, is how Kipling's audience would indeed have read him: "The biblical language and allusions appealed to people who had been educated not only through the Classics but through the Gospels, the Epistles and the Hebrew prophets as well. They understood the message and they accepted it" (118). Just so: if they understood and accepted it, it must have been because they never read it. It is time, God forbid, that we turn to Scripture.

We have an extraordinarily successful poem that by all accounts managed to capture or even mould British group sentiment at a time when the Empire was at its height and, therefore, inevitably, courting decline. "Recessional" somehow manages to mediate this sentiment by articulating it into memorable verse, verse aspiring to the memorability of the Scripture it invokes, verse committed, apparently, to serve the letter of the Law. But at the level of the letter, what it achieves is an irredeemable perversion of the authorized version. Paul's Epistle to the Romans is a deeply tricky text, true to the trickiness of the mission it serves. Nothing could be easier or more beside the point than to confront Kipling's appreciative contemporaries as imagined by Carrington, Gilmour and others with state-of-the-art biblical exegesis, pointing out that Paul's "Gentiles" are not, pace Carrington, the boastful "Roman ruling class," sadly untouched, pace Gilmour, by the "Law of Christ." The point being that all that is needed to make the point of this point is to take a closer look, barely reading, at the verses Carrington quotes and Gilmour copies in

6 Though Gilmour, unlike Carrington who sticks closely to the Authorized Version, twice drops the second "as" in the phrase "as many as" in verse 12. 
the immediate context both appeal to - ultimately, not even that context is required, the text will do. ${ }^{7}$

What does it mean, for instance, in and for Paul, that the Gentiles are "without law," "a law unto themselves"? For Gilmour it seems self-evident: they are "without the Law of Christ" and just do as they like. Yet that is pretty precisely not what the Epistle writes. True, the "oracles of God" (3:2) have only been committed to the Jews, not to the Gentiles, but that is emphatically not the point. Here is the immediate context for the phrase:

\footnotetext{
${ }^{9}$ Tribulation and anguish, upon every soul of man that doeth evil, of the Jew first, and also of the Gentile; ${ }^{10}$ But glory, honour, and peace, to every man that worketh good, to the Jew first, and also to the Gentile: ${ }^{11}$ For there is no respect of persons with God. ${ }^{12}$ For as many as have sinned without law shall also perish without law: and as many as have sinned in the law shall be judged by the law; ${ }^{13}$ (For not the hearers of the law are just before God, but the doers of the law shall be justified. ${ }^{14}$ For when the Gentiles, which have not the law, do by nature the things contained in the law, these, having not the law, are a law unto themselves: ${ }^{15}$ Which shew the work of the law written in their hearts, their conscience also bearing witness, and their thoughts the mean while accusing or else excusing one another;) ${ }^{16}$ In the day when God shall judge the secrets of men by Jesus Christ according to my gospel.
}

The Law that the Gentiles are unto themselves is not some non-principle allowing them to "act as they please," as Gilmour would have us believe, it is none other than the Law itself, now fulfilled through the offices of the Messiah. It is the Law which the Gentiles do not have only in the sense that it has not been taught to them as it has been to the Jews, but which they nonetheless manage to perform. If anybody is guilty of boasting, Paul adds, it is the Jews, not the Gentiles:

${ }^{17}$ Behold, thou art called a Jew, and restest in the law, and makest thy boast of God, ${ }^{18}$ And knowest his will, and approvest the things that are more excellent, being instructed out of the law; ${ }^{19}$ And art confident that thou thyself art a guide of the blind, a light of them which are in darkness, ${ }^{20} \mathrm{An}$ instructor of the foolish, a teacher of babes, which hast the form of knowledge and of the truth in the law. ${ }^{8}$

$7 \quad$ The only commentary on "Recessional" I have come across which devotes some proper, if passing, attention to what Paul actually writes is Keating 116.

8 Later in the letter, admittedly, the Gentiles, for good measure, are warned not to boast either. 
Full of themselves as "light to the Gentiles," elected by God, the Jews fail to see that the Gentiles are ahead of them, performing the Law without even knowing it. They act as they please only in the sense that they do what comes naturally, and what comes naturally to them is the law they have not heard, let alone read, but which is written in their heart.

"Such boastings as the Gentiles use, / Or lesser breeds without the Law" - what can Kipling have been thinking of? Hopkins, Carrington, Gilmour, and others are most probably right in hearing an echo of Paul in these lines; but as even a superficial scan of the Pauline text indicates, they are spectacularly mistaken in assuming that this echo also makes self-evident sense. Or, more accurately, in assuming that the perfect sense the phrase does make actually involves reading it. Like the Gentiles, they understand, accept, and perform the good message without even knowing it, executing the law of meaning which holds that any part shall always be justified by the whole and that every word is always already resolved by the totality of Scripture as essentially unwritten.

It is entirely fitting that this manifest failure to read should be grounded in a claim to reading a letter on the law which is written where it cannot be read. A delirious letter which, according to one recent commentator, "suffers the nemesis of rhetoric, as the flood of language takes over from the meaning," but whose "lapidary antitheses" (among them the "sinned without law"/"sinned in the law"-line) have nonetheless been characterized as "the closest we have to the voice of God" (Goulder 499), a letter written by a postJewish Jew projecting the unread Law of the ever-dissolving Jewish nation (in the beginning, in Genesis 12:2, the Jews too were set, by God, to become a goy, a nation, ethnic, Gentile) into the heart of the Gentiles, the nations to be united under Christ, he (who, he?) who became and thereby denied the word by turning it into the flesh (X marks the spot) which the ever-forming Jewish nation kept confusing with the law of difference, as witness its performance of difference as circumcision, separating the guide goy from the infant goyim.

But what can Kipling have been thinking of? Has he read the Letter to the Romans? Or has he, too, merely understood it? (Or, between brackets, should we entertain the notion, easily googled but hard to pin down, that he was somehow working under the sway of British Israelism and employed 
the implied distinction between the British and the Gentiles not as a convenient mythopoe( $\mathrm{t}$ )ic trope but as historical fact, in the belief that the Anglo-Saxons are the Ten Lost Tribes of Israel expelled by the Assyrians in the 8th century $\mathrm{BC}$ and then displaced to the British Isles? In which case his allusion to Paul amounts to a perverse re-writing of Scripture, denouncing all Gentiles, Judaeans or Jews included, as impostors without the real law of the one original Israeli covenant, which effectively confirms the HopkinsCarrington-Gilmour reading, be it at the cost of Christianity itself. Dan Brown anyone? Close brackets.)

"Lesser breeds without the Law": in Paul, to be without the Law is not to have heard the Law, but not to have heard the Law is ultimately, and astonishingly for a lawgiving letter such as this, immaterial. The verse typically forgotten is Romans 2:13: "For not the hearers of the law are just before God, but the doers of the law shall be justified." Such is the self-suspending non-logic of essential ideology: the conversion of performative prescription into the arch-oxymoron of natural law. ${ }^{9}$ The truth of the law is its performance prior to its performative production. The mission of the legislator is not to transmit the law but to establish it as always already having been there, untouched by material, i.e., linguistic, transmission, as when it is said that it has been established that such (and such) is the case, and the point of the statement is that it does not materially affect the case and instead aspires to radical redundance. ${ }^{10}$ The truth of the law is its denial of the truth that it has to be given in order to be received, that it cannot be forgotten if it hasn't been gotten. This denial is performed when the law styles itself as begotten, transmitted not in writing but by life itself, inscribed beyond inscription and circumcision into the hearts of the goyim-Gentile-ethnic-nations: all of them, but only ever just the One.

9 For an instructive reading of Kipling's "Law" close to my concern here, see Bivona, especially 86-87. Bivona tantalizingly uses Romans 2:14-15 as an epigraph to his chapter on Kipling but fails, so to speak, to establish the law of the allusion.

10 "Do we then make void the law through faith? God forbid: yea, we establish the law" (Romans 3:31). "It is notable that Kipling does not seem to realize, any more than the average soldier or colonial administrator, that an empire is primarily a money-making concern. Imperialism as he sees it is a sort of forcible evangelizing. You turn a Gatling gun on a mob of unarmed 'natives,' and then you establish 'the Law,' which includes roads, railways and a courthouse" (Orwell 186). 
"Recessional" has it right, but no-one is reading. "Breeds" is indeed an "unfortunate" term, destined never to be read. Kipling's apologists - including, of all people, Orwell - go out of their way to deny the referential accuracy of the term: breeds are natural collective entities bonded by bodily fluids; nations or natives or peoples are historical collective entities denying, or being denied, their linguistic constitution through the imagination of the inscriptions they live by as transcriptions of breed bonds. Nations are built on the systematic confusion of reading with breeding: they are always without the law because the law that they are unto themselves is the imaginary unwritten law of nature in which the law as law always already aspires to lose itself so as to become what it irrevocably abandons at the time, every time, of inscription.

All breeds are equal in that, as breeds, they are without the law. If some breeds are lesser than others, such as the Gentiles, and we are all Gentiles, that is not because they are without the law but because when breeds meet they are haunted by inscription and deny themselves the denial of the law, the law of the law, and re-imagine themselves, as opposed to the opposite breed, as having heard, even as having read, the law. Not that this differentiation makes any difference, for no nation can survive reading its own law. Which is why, as Paul writes, as Kipling miswrites, they boast about it, and then boast about not boasting about it. Anything to avoid reading. Anything to avoid exile and alienation.

"Lest we forget." Forget what, exactly? Though nations define themselves as repositories of collective memory, as nations they owe their existence to oblivion. "Lest we forget" to forget what makes memory possible in the first place: lest we begin to read - God forbid - that We are not of One Blood, that Blood doesn't enter into it, that God is the thing we invent to forget that the law is still waiting to be read. Unto itself, the law is never a law. But that is not how it works. "Recessional" works by producing a surface commanding recognition, a specular phantasm sustaining the referential illusion that it represents the blood of the first person plural in whose pronoun it speaks. In textual fact, it represents what is really written, not in the living heart but in the dead letter of difference which lays any natural we to waste and abandons us to the post-human burden of reading. But that, in turn, as they say, is history: the great unread. 
It is tempting to wrest a moral from this story of a text that manifestly succeeded in giving shape to the sense of an Empire by blindly recycling bits of a text that managed to give shape to one of the greatest hyper-Empires in human history, against all odds, including its own eccentricities, for better or worse. Let us not resist that temptation. Let us take courage from the fact that our Constitution (who, we?) is not ratified and remains to be read. And by all means let our Constitution name Christianity and its crazes and crises as constitutive of Europe, lest this unreadable heritage be assumed and forgotten in the rapture of final understanding.

\section{Works Cited}

Arac, Jonathan. "Chinese Postmodernism: Towards a Global Context." boundary 224.3 (1997): 261-75.

Birkenhead, Lord. Rudyard Kipling. London: Weidenfeld and Nicholson, 1978.

Bivona, Daniel. "Kipling's 'Law' and the Division of Bureaucratic Labor." British Imperial Literature, 1870-1940: Writing and the Administration of Empire. Cambridge: Cambridge University Press, 1998. 69-98.

Bodelsen, C.A. Review of Rudyard Kipling, Realist and Fabulist by Bonamy Dobrée and Rudyard Kipling's India by K. Bhaskara Rao. The Review of English Studies (New Series) 19.75 (1968): 334-37.

Brantlinger, Patrick. "Kipling's 'The White Man's Burden' and Its Afterlives." English Literature in Transition, 1880-1920 50.2 (2007): 172-91.

Carrington, C.E. “The Lesser Breeds." Kipling Journal 164 (1967): 14.

Gilmour, David. The Long Recessional: The Imperial Life of Rudyard Kipling. London: Pimlico, 2003.

Goulder, Michael. “The Pauline Epistles." The Literary Guide to the Bible. Ed. Robert Alter and Frank Kermode. Cambridge: Harvard University Press, 1987. 479-502.

Huxley, Julian S., A.C. Haddon, and A.M. Carr-Saunders. We Europeans: A Survey of "Racial" Problems. Harmondsworth: Penguin, 1939.

Judd, Denis. “Diamonds Are Forever? Kipling's Imperialism." History Today 47.6 (1997): 37-43.

Keating, Peter. Kipling the Poet. London: Secker and Warburg, 1994.

Kucich, John. "Sadomasochism and the Magical Group: Kipling's Middle- 
Class Imperialism." Victorian Studies 46.1 (2004): 33-68.

Newsom, George. “'Recessional' and 'The White Man's Burden." Kipling Journal 255 (1990): 13-24.

Orwell, George. "Rudyard Kipling." My Country Right or Left, 1940-1943.

The Collected Essays, Journalism, and Letters of George Orwell. 2nd vol. Ed. Sonia Orwell and Ian Angus. London: Secker and Warburg, 1968. 184-97.

Parry, Ann. The Poetry of Rudyard Kipling: Rousing the Nation. Buckingham: Open University Press, 1992.

Tombs, Robert. "Lesser Breeds without the Law': The British Establishment and the Dreyfus Affair, 1894-1899." The Historical Journal 41.2 (1998): 495-510. 